\title{
On the behaviour of the tropopause folding events over the Tibetan Plateau
}

\author{
X. L. Chen ${ }^{1,2}$, Y. M. Ma ${ }^{1}$, H. Kelder ${ }^{3}$, Z. Su ${ }^{2}$, and K. Yang ${ }^{1}$ \\ ${ }^{1}$ Key Laboratory of Tibetan Environment Changes and Land Surface Processes, Institute of Tibetan \\ Plateau Research, Chinese Academy of Sciences, Beijing, China \\ ${ }^{2}$ Faculty of Geo-Information Science and Earth Observation of the University of Twente, \\ Enschede, The Netherlands \\ ${ }^{3}$ Faculty of Physics, Eindhoven University, Eindhoven, The Netherlands
}

Received: 27 January 2010 - Published in Atmos. Chem. Phys. Discuss.: 6 October 2010

Revised: 20 April 2011 - Accepted: 29 April 2011 - Published: 31 May 2011

\begin{abstract}
Due to its harsh natural conditions, there had not been any intensive radiosonde observations over the Tibetan Plateau (TP) before the year 2008, when a regional radiosonde observation network was implemented through a Sino-Japan joint cooperation project. This paper reports, on the basis of these observations, on an analysis of the structure of upper troposphere and lower stratosphere (UTLS) and provides observations of stratosphere and troposphere exchange (STE) over the TP.

Due to sparseness of high resolution radiosonde data, many previous studies assumed that there was only one thermal tropopause over the TP. Actually, the radiosonde temperature profiles in winter time over the TP often exhibit a multiple tropopause (MT). The MT occurs in winter with a high frequency over the Plateau. MT events during this time are associated with tropopause folds near the subtropical westerly jet. The MT consistently varied with the movement of the jet. The MT becomes a single tropopause with the development of the monsoon. The detailed analyses of MT characteristics are reported in this paper.

Earlier analyses of global MT events (with data based on GPS radio occultation, ERA-40 data and Integrated Global Radiosonde Archive database) resulted in a climatic frequency of MT occurrences in the winter season over the Plateau is not more than $40 \%$. Based on high resolution data of intensive radiosonde observations, our estimations of MT occurrence over the Plateau can be as high as $80 \%$ during
\end{abstract}

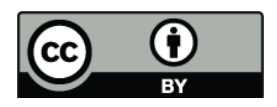

Correspondence to: X. L. Chen (chen24746@itc.nl) certain winters. This reminds us to pay more attention to the MT events above the Plateau. The influence of the coarse vertical resolution and other effects on the estimation of MT occurrence frequency are also discussed.

The stratospheric intruding episodes are generally associated with the presence of subtropical jet stream over the Plateau. The complex structure of dynamic tropopause folding over the Plateau have been reflected by the thermal MT events observed by radiosondes. The intrusion of air masses from the stratosphere may contribute to a higher upper tropospheric ozone concentration in winter than in summer above the plateau.

\section{Introduction}

The Tibetan Plateau (TP) has an average height of over $4000 \mathrm{~m}$ and an area of 2.5 million $\mathrm{km}^{2}$ and exerts a profound thermal and dynamic influence on the Asian monsoon and global weather and climate. Due to the low air density and the strong solar radiation, the TP allows more energy from the surface, directly heating the middle troposphere. This heat can influence the upper troposphere and warms the tropopause region (Fu et al., 2006). The exchange between upper troposphere and lower stratosphere (UTLS) was found over the Tibetan Plateau (Cong et al., 2002; Fu et al., 2006; Steinwagner et al., 2007; Sprenger et al., 2003; Zhan and Li, 2008). As a huge elevated heating source, a rigorous deep convection area (Yang et al., 2004), a dynamical pumping and sucking unit (Duan et al., 2005), and westerly jet above it, the TP generates an active stratosphere and troposphere

Published by Copernicus Publications on behalf of the European Geosciences Union. 
exchange (STE) region, forming a short-circuit and pathway for the STE (Fu et al., 2006). An improved understanding of the STE depends on our ability to quantify the UTLS structure and its variability (Stohl et al., 2003). Due to a lack of high resolution observational data, the structure of the UTLS above the Tibetan Plateau is still insufficiently understood (Gettelman et al., 2010; Hegglin et al., 2010; SPARC Report, 2010).

The occurrence of multiple tropopauses (MT) plays a central role in the structure and features of the tropopause layer which plays a crucial role in the exchange between the troposphere and stratosphere above the TP (Añel et al., 2008). Both Añel et al. (2008) (employing Integrated Global Radiosonde Archive database) and Randel et al. (2007) (based on GPS radio occultation measurements and ERA-40) have derived global statistics of MT. The present paper presents statistics of MT and STE events above the Tibetan Plateau based on high resolution sonde data for the first time. Therefore, it will contribute to MT statistics of Añel et al. (2008) and Randel et al. (2007) and helps us to understand the exchanges between the stratosphere and troposphere over the Tibetan Plateau.

Tropopause folds are the key feature and favourable structures for cross-tropopause exchange in the subtropics (Sprenger et al., 2003; Shapiro, 1980); The frequency of tropopause folds is highest in the subtropics related to the prevailing subtropical upper level jet stream (Reed, 1955; Schmidt et al., 2005; Randel et al., 2007). The Tibetan Plateau is situated at $28^{\circ} \mathrm{N}-38^{\circ} \mathrm{N}$, a region which is significantly influenced by the subtropical jet stream as it moves northward from winter to summer. Sprenger et al. (2003) have analysed the frequency and global distribution of tropopause folds. Their results demonstrate that the global frequency of shallow folds above the Plateau is highest during winter (see figure 3 in Sprenger et al., 2003).

Meanwhile, satellite observations of ozone have shown "Ozone Mini-Hole" events and ozone valley phenomena over the Plateau (Zhou et al., 2005; Tobo et al., 2008; Bian, 2009). The mechanisms responsible for the low total ozone have been discussed. Previous studies suggest that the transport of tropospheric air with low ozone concentration across the tropopause influences the low ozone concentration in the lower stratosphere in summer (Zhou et al., 1995; Zou, 1996). Tian et al. (2008) found that the variability of the total column ozone over the TP is closely related to uplift and descent of isentropic surfaces. Tobo et al. (2008) observed ozone anomalies near the tropopause $(150-70 \mathrm{hPa})$ having a large contribution to the low total ozone. Intrusions of stratospheric air masses with high ozone concentration into the troposphere were closely associated with tropopause folds (Reed, 1955; Sprenger et al., 2003; Beekmann et al., 1997). Due to the high frequency of tropopause folds (Sprenger et al., 2003), stratosphere intrusions should frequently happen over the Plateau. These downward transports of rich ozone air strongly influence the vertical ozone distribution espe-

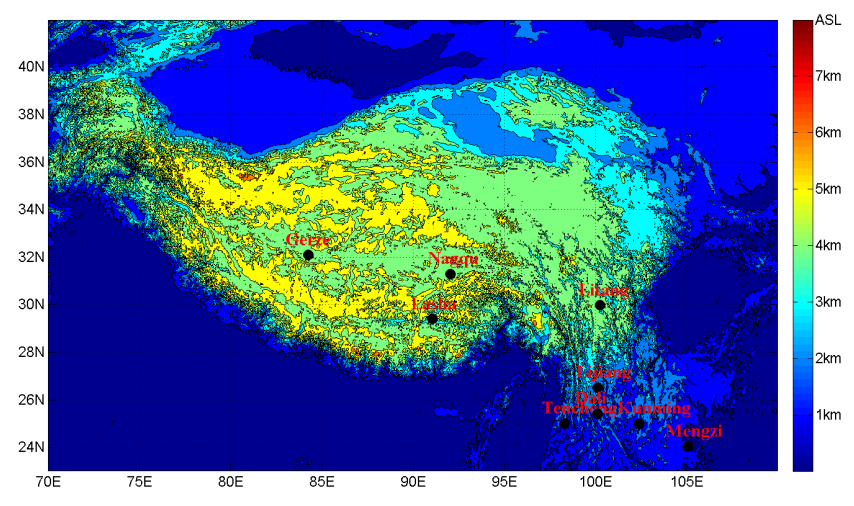

Fig. 1. Distribution of radiosonde sites over the Tibetan Plateau (ASL-elevation above sea level).

cially at UTLS area over the Plateau. However, the variation of the stratospheric intrusions and their influence on the vertical ozone distribution need further analyses.

In order to understand the atmosphere heating and water vapour variations over the TP during different phases of the monsoon, the Sino-Japan joint cooperation project was carried out to collect intensive radiosonde observations in 2008 (Xu et al., 2008). As illustrated in Fig. 1, nine radiosonde observation sites are included in our study. Four sites (Gerze, Lasha, Nagqu, and Litang) were situated on the Plateau. The height of other stations was lower than $2000 \mathrm{~m}$ a.s.l. These sites will be discussed as low altitude observations.

There is a lack of high resolution information of the tropopause above the Plateau. This study will contribute to characteristics of MT events using the most advanced radiosonde data in this area. Section 2 describes observational data and the tropopause definition. The MT characteristics are presented in Sect. 3. Section 4 discusses dynamic characteristics of tropopause folds accompanied by thermal MT events during the Sino-Japan joint cooperation project. Section 5 summarizes the study with conclusions and discussions.

\section{Observation data and tropopause definition}

Three sites, Gerze, Litang and Dali, were equipped with a Vaisala DigiCORA III GPS radiosonding system. The radiosondes used were Vaisala RS92 calibrated with local meteorological measurements before releasing. The sounding data contained profiles of temperature, pressure, relative humidity, horizontal wind speed and direction. Utilizing differential GPS theory, the receiver can automatically compute the height of the sensor and the wind speed. The radiosonde transmits data to the receiver every $2 \mathrm{~s}$. With an average $5 \mathrm{~m} \mathrm{~s}^{-1}$ ascending speed, the obtained vertical resolution of the data is about $10 \mathrm{~m}$. The other six sites employed the Chinese meteorological radiosonde system (detailed information about the radiosonde can be found at the following website: 
http://www.cwqx.com/). These systems can observe temperature, pressure, humidity, wind speed and direction at a vertical resolution of $100 \mathrm{~m}$. All the observation data are interpolated to $20 \mathrm{~m}$ vertically equal-spaced levels using the splines method for the convenience of detailed analysis and comparison.

Three intensive observation periods (IOP) were carried out. Detailed information about the observation dates are shown in Table 1. The first observation period (IOP1) was aimed at winter time. The second observation period (IOP2) was conducted in the period of monsoon onset time. The third observation period (IOP3) was almost in the mature phase of monsoon. Four radiosondes were released every day at 01:00, 07:00, 13:00 and 19:00 local standard time (LT).

For computing the tropopause height, we employ the WMO lapse rate tropopause (LRT) definition (World Meteorological Organization, 1957):

(a) The first tropopause is defined as the lowest level at which the lapse rate decreases to $2 \mathrm{~K} \mathrm{~km}^{-1}$ or less, provided also that the average lapse rate between this level and all higher levels within $2 \mathrm{~km}$ does not exceed $2 \mathrm{~K} \mathrm{~km}^{-1}$.

(b) If above the first tropopause the average lapse rate between any level and all higher levels within $1 \mathrm{~km}$ exceeds $3 \mathrm{~K} \mathrm{~km}^{-1}$, then a second tropopause is defined by the same criterion as (a).

The first tropopause is denoted by LRT1, and if a further tropopause is present above LRT1, it is named LRT2 and then LRT3. Double tropopause (DT) is denoted by detection of LRT1 and LRT2. Triple tropopause (TT) is identified as profile detected with LRT1, LRT2 and LRT3.

\section{Multi-tropopause observed by radiosonde}

In previous studies, little attention was paid to MT events over the Plateau. During the intensive observation period, a frequent strong thermal inversion layer presents around $10 \mathrm{~km}$ above Gerze station $\left(32.09^{\circ} \mathrm{N}, 84.25^{\circ} \mathrm{E}\right)$ situated at the western Plateau. MT is calculated for the IOP1 period using the MT definition of WMO (1957) and it is proven that MT often happened during IOP1. Examples of the DT temperature profiles from Gerze station are shown in Fig. 2a. Continuous radiosonde data for 25 February 2008, 01:00 LT to 26 February 2008, 13:00 LT are exhibited. The profiles show a tropopause identified around $300 \mathrm{hPa}$, and a second tropopause detected near $100 \mathrm{hPa}$. Figure $2 \mathrm{~b}$ reveals profiles from 29 February 2008, 01:00 to 1 March 2008, 13:00 LT with only one tropopause above $100 \mathrm{hPa}$. We will explain what causes the difference in UTLS structure in these two time periods in Sect. 4.

Employing the WMO LRT definition to all the stations, we computed MT frequencies of the three IOPs, and listed
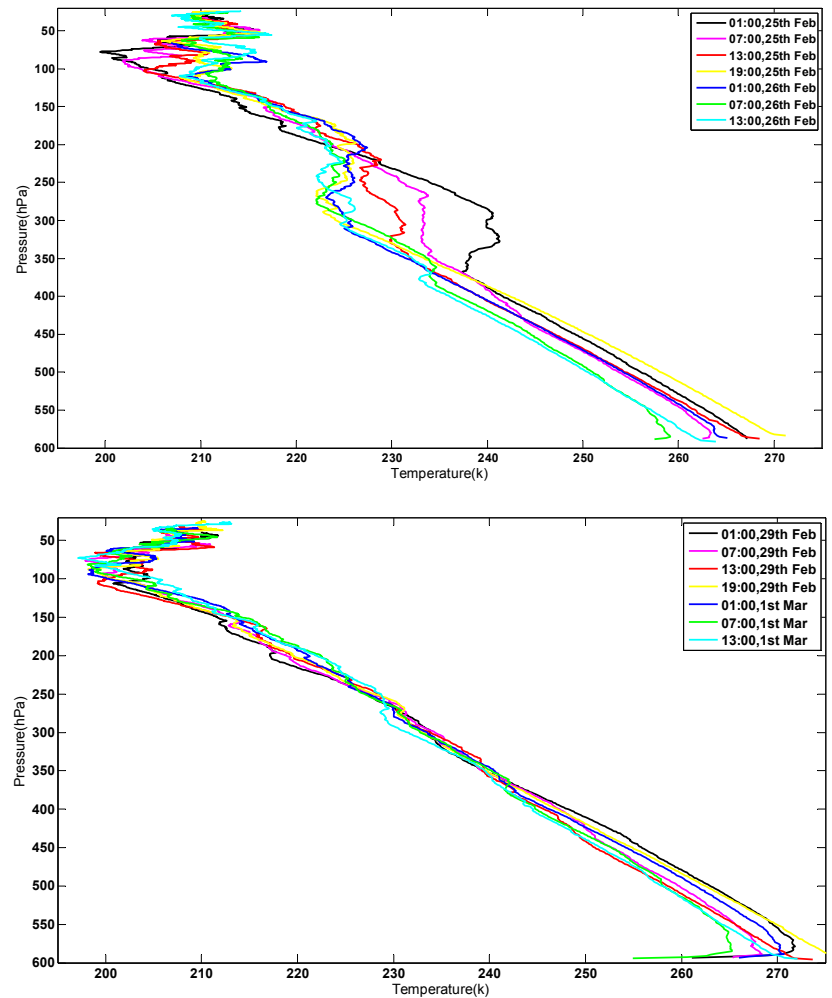

Fig. 2. (a) Temperature profiles from 25 February 2008, 01:00 to 26 February 2008, 13:00 LT at Gerze site. (b) Temperature profiles from 29 February 2008, 01:00 to 1 March 2008, 13:00 LT at Gerze site.

them in Table 2. The frequency of the MT events is given as a percentage with respect to the number of LRT1 events. The MT occurrences of the three Plateau stations (Gerze, Nagqu and Litang) for IOP1 are as high as from $72.5 \%$ to $84 \%$. Our analyses show that the frequency and seasonal variation of MT events are high during winter. The frequency of MT (discussed with Randel) derived from the GPS occultation data and the ERA-40 data during DJF (December, January and Feburary) in Randel et al. (2007) on the Plateau was not more than $40 \%$ in their Fig. 9a and A1b. Añel et al. (2008) analysed global MT events performed on the Integrated Global Radiosonde Archive database (IGRA). As shown in their Fig. 2, the percentage of DT occurrence had less seasonal variation and the value of DJF is not more than $20 \%$ above the Plateau. Thus, more attention should be paid to the MT events above the Plateau and the influence of the low vertical resolution of GPS and ERA-40 data on the estimation of MT events.

At the Dali site, which has an elevation of $1960 \mathrm{~m}$ and locates out of the Plateau, the MT occurrence of IOP1 is about $12.9 \%$. This value is much lower than that of other stations. We also picked out the radiosondes of the same date in each IOP. The statistics suggest that when moving to the southern and low areas, the frequency of MT becomes lower. The MT 
Table 1. Intensive observation dates of the three periods in 2008.

\begin{tabular}{|c|c|c|c|c|c|}
\hline & Gerze & Lasha & Nagqu & Litang & Lijiang \\
\hline IOP1 & 25 Feb-19 Mar & $X$ & 25 Feb-19 Mar & 7 Mar-16 Mar & $\mathrm{X}$ \\
\hline IOP2 & 13 May-12 Jun & $\mathrm{X}$ & $\mathrm{X}$ & 13 May-22 May & $\mathrm{X}$ \\
\hline \multirow[t]{2}{*}{ IOP3 } & 7 Jul-16 Jul & 20 Jun-19 Jul & $\mathrm{X}$ & 7 Jul-16 Jul & 20 Jun-19 Jul \\
\hline & Dali & Tengchong & Kunming & Mengzi & \\
\hline IOP1 & 7 Mar-15 Mar & $X$ & $\mathrm{X}$ & $X$ & \\
\hline IOP2 & 13 Мay-22 May & $X$ & $X$ & $\mathrm{X}$ & \\
\hline IOP3 & 7 Jul-16 Jul & 20 Jun-19 Jul & 20 Jun-19 Jul & 20 Jun-19 Jul & \\
\hline
\end{tabular}

$\mathrm{X}$ means no observation data.
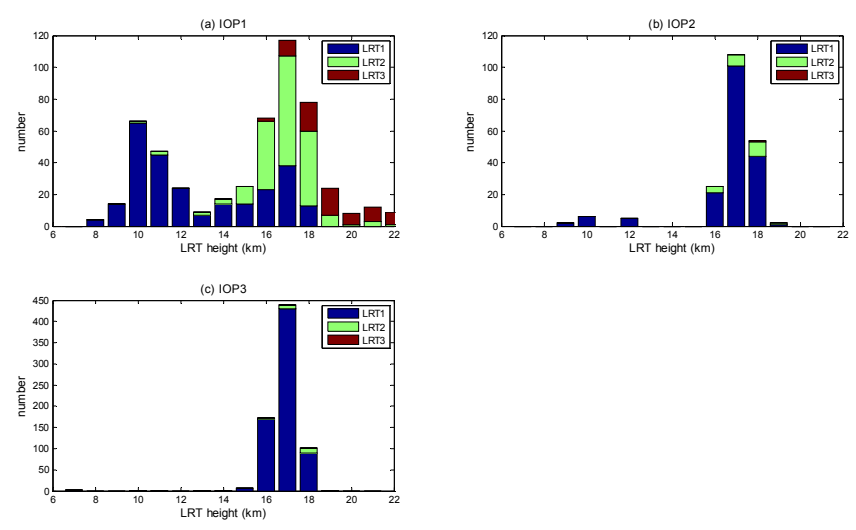

Fig. 3. Distribution of multi-tropopause heights at different phases of the monsoon. The first tropopause (LRT1), second tropopause (LRT2) and third tropopause (LRT3) are displayed by blue, green and brown, respectively. Table 1 lists which sites and data are analysed in these three IOPs.

frequencies of all the Plateau stations during IOP3 are the lowest compared to the other two periods. This result supports the conclusion of MT occuring in winter time with a high frequency over the Plateau, which is similar to previous climatological studies.

Figure 3 shows the statistical distributions of the MT height during the three IOPs. The statistics for IOP1 demonstrate an overall bimodal distribution with maxima near $10 \mathrm{~km}$ (primarily associated with LRT1) and $17 \mathrm{~km}$ (firstly contributed by LRT2). According to the significant difference in the two tropopause heights, we mark them separately as "low" and "high" tropopause. LRT1 is more inclined to low tropopause during this time. The majority of the LRT2 height in IOP1 is around $17 \mathrm{~km}$, which is closer to high tropopause of the equatorial area. The statistics of IOP2 and IOP3, in Fig. 3, show a single maximum (primarily LRT1) centred at $17 \mathrm{~km}$, which means MT is rarely observed during the monsoon season.

Khalili (1975) observed a significant negative correlation between the tropopause height and its temperature. We also analysed the relationship between the tropopause height and temperature. Both LRT1 and LRT2 heights are in opposite phases with their temperature scaled in hours as shown in Fig. 4. LRT3 does not show this character, suggesting itself as a lower stratosphere layer (Añel et al., 2007; Gettelman and Forster, 2002). On the contrary, LRT1 and LRT2 should be attributed to tropospheric stable layers.

The average heights of DT during the three periods are listed in Table 3. LRT1 of the three Plateau stations (Gerze, Nagqu and Litang) have heights around 11-13 km during IOP1. These tropopauses can be treated as low tropopauses. For all observation periods and sites, LRT2 is characterised by a height around $17 \mathrm{~km}$. After the monsoon onset, the LRT1 height over the Plateau was elevated to $4-5 \mathrm{~km}$, indicating the disappearance of the low tropopause. This can be explained as a result of both the Plateau's thermal forcing, which causes large-scale ascent flow and vertical convection, and the poleward movement of the jet stream. Tian et al. (2008) suggested the thermal sink (source), by forcing a descent (ascent) flow, lowers (lifts) the tropopause. The thermal dynamic effects of the Plateau can be one reason for the seasonal variation of the tropopause, but does not seem probable in explaining variations from $10-17 \mathrm{~km}$ in the LRT1 height during winter time. Our explanation will be presented in the next section.

\section{The tropopause folds over the Tibetan Plateau}

It is well known that the altitude variation of tropopause in the extratropics has a close relationship with the local synoptic situation. In order to analyse the meteorological situation associated with the single and double tropopauses, we use the ERA-40 reanalysis data provided by ECMWF, the European Centre for Medium-Range Weather Forecasts (Uppala et al., 2005). We take 25 February 2008, 12:00 LT (Fig. 5a) and 29 February 2008, 12:00 LT (Fig. 5b) as first examples. During these two times, DT and single tropopause were observed at Gerze. Figure 5 includes potential vorticity (PV) isolines (units: 1 PVU), zonal wind and potential 
Table 2. Frequency of multiple tropopause (MT) during the three observation periods.

\begin{tabular}{cccccccccc}
\hline & Gerze & Lasha & Nagqu & Litang & Lijiang & Dali & Tengchong & Kunming & Mengzi \\
\hline IOP1 & $84 \%$ & $\mathrm{X}$ & $78.6 \%$ & $72.5 \%$ & $\mathrm{X}$ & $12.9 \%$ & $\mathrm{X}$ & $\mathrm{X}$ & $\mathrm{X}$ \\
IOP2 & $12.3 \%$ & $\mathrm{X}$ & $\mathrm{X}$ & $5 \%$ & $\mathrm{X}$ & $13 \%$ & $\mathrm{X}$ & $\mathrm{X}$ & $\mathrm{X}$ \\
IOP3 & $0 \%$ & $2.5 \%$ & $\mathrm{X}$ & $2.6 \%$ & $4.2 \%$ & $2.5 \%$ & $4.2 \%$ & $5 \%$ & $4.7 \%$ \\
\hline
\end{tabular}

$\mathrm{X}$ means no observation data.

Table 3. Average height of LRT during the three observation periods.

\begin{tabular}{|c|c|c|c|c|c|c|c|c|c|c|}
\hline & \multicolumn{2}{|c|}{ Gerze } & \multicolumn{2}{|c|}{ Lasha } & \multicolumn{2}{|c|}{ Nagqu } & \multicolumn{2}{|c|}{ Litang } & \multicolumn{2}{|c|}{ Lijiang } \\
\hline & LRT1 & LRT2 & LRT1 & LRT2 & LRT1 & LRT2 & LRT1 & LRT2 & LRT1 & LRT2 \\
\hline IOP1 & $12359 \mathrm{~m}$ & $16914 \mathrm{~m}$ & $X$ & $\mathrm{X}$ & $11976 \mathrm{~m}$ & $16789 \mathrm{~m}$ & $13041 \mathrm{~m}$ & $16890 \mathrm{~m}$ & $X$ & $X$ \\
\hline IOP2 & $16470 \mathrm{~m}$ & $17335 \mathrm{~m}$ & $X$ & $X$ & X & X & $17338 \mathrm{~m}$ & $17980 \mathrm{~m}$ & $X$ & $X$ \\
\hline \multirow[t]{3}{*}{ IOP3 } & $17289 \mathrm{~m}$ & $X$ & $16734 \mathrm{~m}$ & $17568 \mathrm{~m}$ & $X$ & $X$ & $16885 \mathrm{~m}$ & $17860 \mathrm{~m}$ & $16948 \mathrm{~m}$ & $17662 \mathrm{~m}$ \\
\hline & \multicolumn{2}{|c|}{ Dali } & \multicolumn{2}{|c|}{ Tengchong } & \multicolumn{2}{|c|}{ Kunming } & \multicolumn{2}{|c|}{ Mengzi } & & \\
\hline & LRT1 & LRT2 & LRT1 & LRT2 & LRT1 & LRT2 & LRT1 & LRT2 & & \\
\hline IOP1 & $16193 \mathrm{~m}$ & $18185 \mathrm{~m}$ & $X$ & $\mathrm{X}$ & $\mathrm{X}$ & $X$ & $X$ & $X$ & & \\
\hline IOP2 & $16962 \mathrm{~m}$ & $17468 \mathrm{~m}$ & $X$ & $X$ & $X$ & $X$ & $X$ & $X$ & & \\
\hline IOP3 & $16862 \mathrm{~m}$ & $17960 \mathrm{~m}$ & $16925 \mathrm{~m}$ & $17636 \mathrm{~m}$ & $16887 \mathrm{~m}$ & $17283 \mathrm{~m}$ & $16459 \mathrm{~m}$ & $16106 \mathrm{~m}$ & & \\
\hline
\end{tabular}

$\mathrm{X}$ means no observation data.
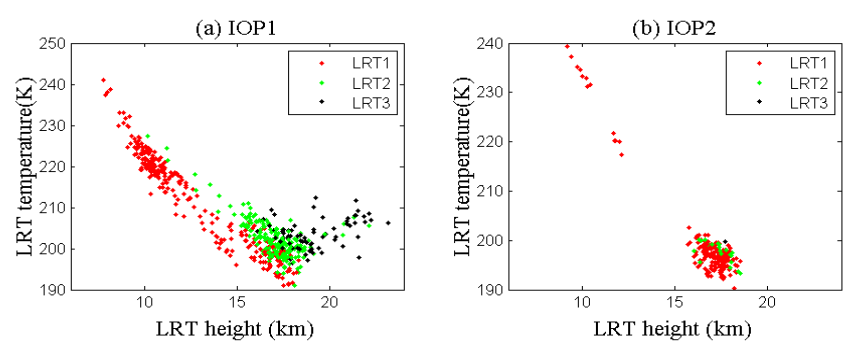

(c) IOP3

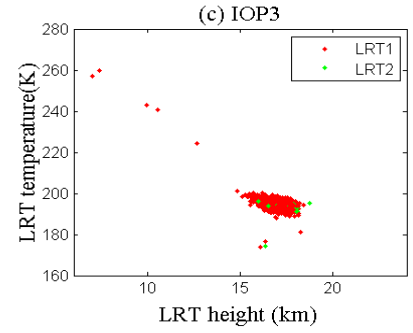

Fig. 4. Multi-tropopause heights versus temperatures. The first tropopause (LRT1), second tropopause (LRT2) and third tropopause (LRT3) are displayed by red, green and black, separately. Table 1 lists which sites and data are analysed in these three IOPs.

temperature derived from ERA-40 data. Inverted triangles show simultaneous tropopause heights observed at the two stations of Gerze and Nagqu. In order to exactly locate their positions of thermal tropopause, we interpolated the ERA-40 $1.5^{\circ}$ latitudinal resolution to $0.1^{\circ}$, and pressure levels lower than $400 \mathrm{hPa}$ to $10 \mathrm{hPa}$, higher than $400 \mathrm{hPa}$ to $25 \mathrm{hPa}$ vertical resolution with the spline method. Due to the westerly wind, the soundings were usually moved to the east with a relative small north-south variation. The positions of MT observed by simultaneous radiosondes were marked by the same latitude as its station point in Fig. 5.

A method to identify the dynamical tropopause is based on potential vorticity (PV). A series of PV isolines (PV $=1-$ 5 PVU) were plotted to indicate the approximate location of the dynamical tropopause (blue lines in Fig. 5). A principal indicator of intrusion of stratospheric air into troposphere is the occurrence of anomalous high PV values reaching down towards middle troposphere. It is because PV is generally greater in the stratosphere than in the troposphere (Holton, 2004). Figure 5a shows that the westerly jet stream is at a latitude of $30^{\circ} \mathrm{N}$ above the TP. The observed maximum wind speed is higher than $60 \mathrm{~m} \mathrm{~s}^{-1}$ at $160 \mathrm{hPa}$ level. The PV isolines were distorted in the vicinity of the northern edge of the subtropical jet stream. The $2 \mathrm{PVU}$ isosurface reaches down to $380 \mathrm{hPa}$ over the Plateau. Folds around $30^{\circ} \mathrm{N}$ is identified on isentropic surfaces between $300 \mathrm{~K}$ and $340 \mathrm{~K}$ penetrating deeply into the troposphere in Fig. 5a. The dynamical tropopause (identified by $1-5 \mathrm{PVU}$ ) exhibit a medium folded structure (Sprenger et al., 2003) over the Plateau which indicates a strong stratospheric intrusion. The entrainment of stratospheric air within the folds is marked both by high PV values and high ozone concentration (see supplementary Sciamachy ozone product of 25 February 2008). The 


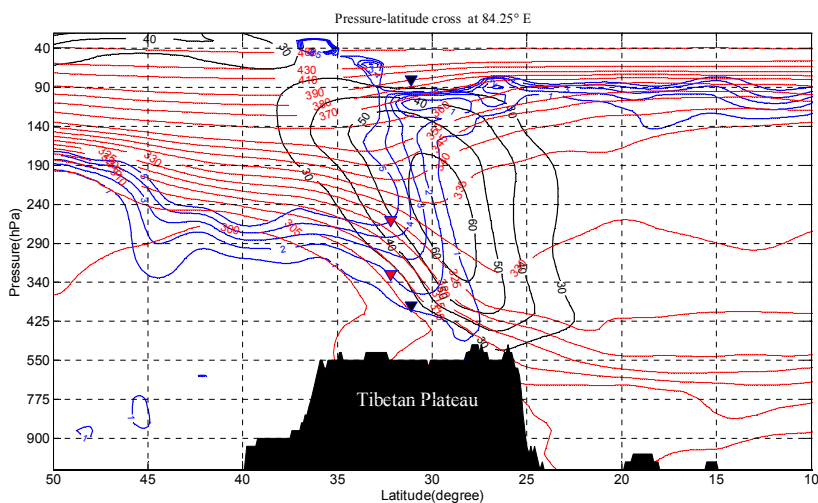

Pressure-latitude cross at $84.25^{\circ}$

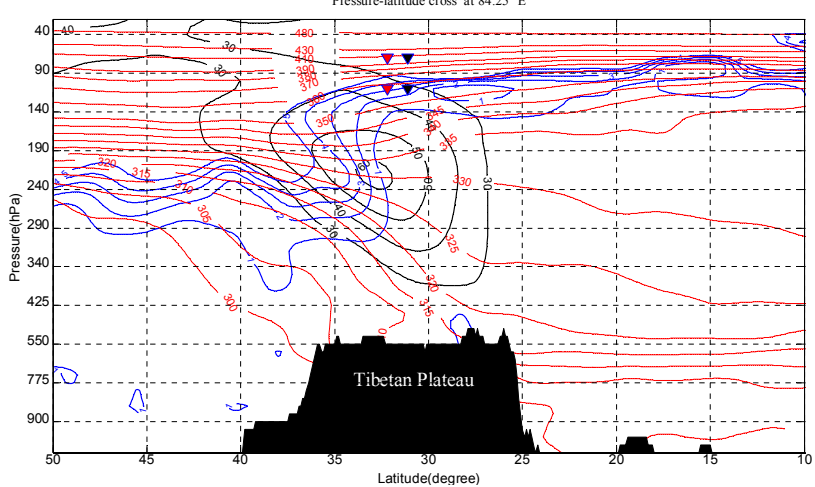

Fig. 5. (a) Meridional cross-section at $84.25^{\circ} \mathrm{E}$ (over Gerze site) on 25 February $2008,12: 00$ LT between $10^{\circ} \mathrm{N}$ and $50^{\circ} \mathrm{N}$ in latitude and between $1000 \mathrm{hPa}$ and $20 \mathrm{hPa}$ in the vertical derived from ERA-40 data, including zonal winds (black contours, $\mathrm{m} / \mathrm{s}$ ), potential vorticity (PV) (blue lines, contours of 1-5 PVU units) and potential temperature (red contours, $\mathrm{K}$ ). The red and black triangles were tropopauses observed at Gerze and Nagqu station. (b) same as Fig. 5. (a) but for 29 February 2008, 12:00 LT.

ozone profile around $30^{\circ} \mathrm{N}$ shows the intrusion caused by the tropopause fold. The ERA-40 ozone distributions around folds were found to be a coincident with that of PV (see Fig. 6). Figure 6 shows the dynamical effects of wind on 25 February 2008. The tongue of high ozone air were transported from polar stratosphere to middle troposphere above the Plateau by southern downward meridional wind on the polarward side of the jet streams as shown in Fig. 6. The time series of the same pictures as Fig. 5 from 25 February 2008, 01:00 LT to 26 February 2008, 13:00 LT show the development of the folds into deep and shallow events (supplementary figure), propagating from north to south. The deepest folds were classified as medium folds during this time (Sprenger et al., 2003). Because of the high elevation of the Plateau, the intrusions can easily transport stratospheric air mass to its ground.

A similar meteorological situation on 29 February 2008, 12:00 LT (Fig. 5b) was further used to study single tropopauses. The second tropopause at $70 \mathrm{hPa}$ observed by radiosondes in Fig. 5b should be a stratospheric layer, not

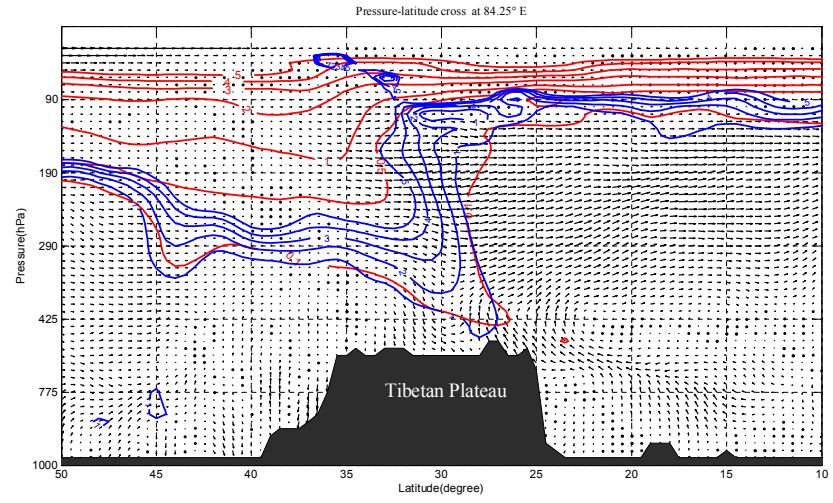

Fig. 6. Pressure-latitude cross-section of meridional wind vector (blue arrow, $\mathrm{ms}^{-1}$ ), ozone mass mixing ratio (red contours, $10^{-6} \mathrm{~kg} \mathrm{~kg}^{-1}$ ) and potential vorticity (PV) (blue lines, contours of 1-5 PVU units) at $84.25^{\circ} \mathrm{E}$ (over the Gerze site) on 25 February 2008, 12:00 LT between $10^{\circ} \mathrm{N}$ and $50^{\circ} \mathrm{N}$ in latitude and between $1000 \mathrm{hPa}$ and $20 \mathrm{hPa}$ in the vertical derived from ERA-40 data. The wind vector shows meridional divergent wind $\left(\mathrm{m} \mathrm{s}^{-1}\right)$ with vertical velocity $\left(\mathrm{Pa} \mathrm{s}^{-1}\right)$ exaggerated by 60 times.

real tropopause. Thus, the profile at this time is taken as a single tropopause event. The jet core (defined as the centre of wind speed higher than $50 \mathrm{~m} \mathrm{~s}^{-1}$ ) moved northward to $33^{\circ} \mathrm{N}$, on the north of Gerze and Nagqu site. The shallow folded structure (Sprenger et al., 2003) at this time retreated to the north of the Plateau. The equatorial tropopause extends over the South Plateau. The dynamical tropopause indicates no folds above the two stations. The radiosonde data show high thermal tropopauses at both the stations.

The jet core positions, in both periods of Fig. 2, were compared. From 25 February 2008, 0:00 to 26 February 2008, 13:00 LT, the jet core propagates from around $32^{\circ} \mathrm{N}$ to $26^{\circ} \mathrm{N}$. The tropopause folds also have coordinated displacement when the radiosondes at Gerze site observed MT events (Fig. 2a). During the single tropopause periods from 29 February 2008, 01:00 to 1 March 2008, 13:00 LT in Fig.2b, the jet core locates at $32^{\circ} \mathrm{N}-33^{\circ} \mathrm{N}$. The tropopause folds also move northward and weaken compared to folds observed during the period of double tropopause. The folds have less influence upon the UTLS above Gerze station. The tropical tropopause has entered the station, which reflects a high tropopause in this period. According to the analysis of these two time series, the tropopause folds follow the displacement of the subtropical jet over the Plateau. This process significantly influences the structure of UTLS above the Plateau.

Stratospheric intrusions of air usually occur with tropopause folds. A frequent descent air circulation above the Plateau has been observed during winter (e.g., Yanai et al., 1992). This flow strongly favours stratospheric intrusions into the troposphere during winter. Seasonal changes in PV in a pressure-longitude cross-section do not reveal any folds (see supplementary Fig. 7a). This suggests that meridional 


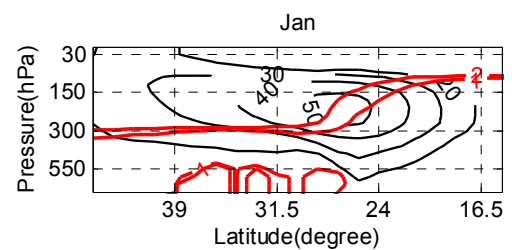

Apr

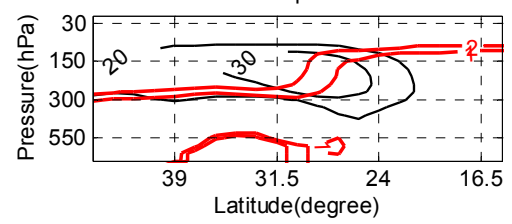

Jul

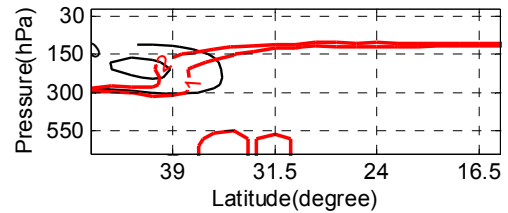

Oct

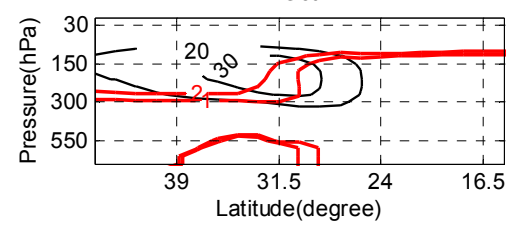

Feb

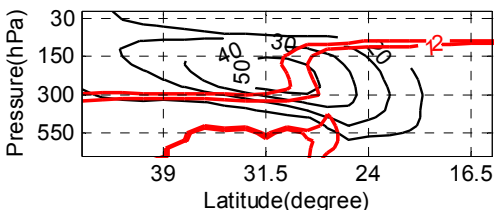

May

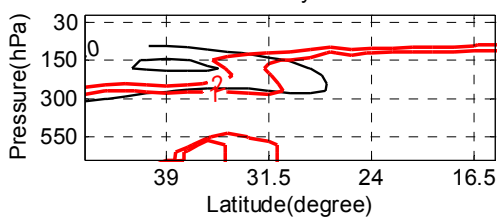

Aug

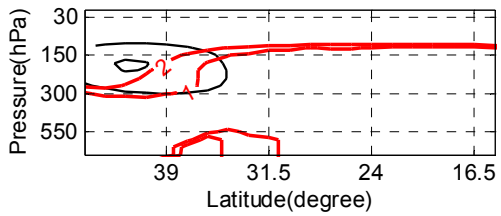

Nov

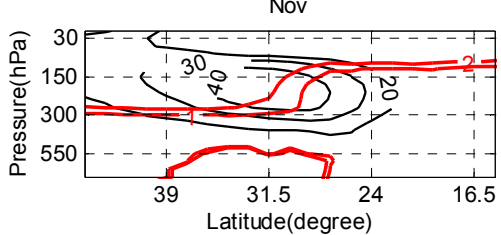

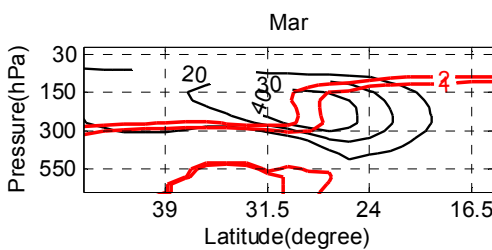

Jun

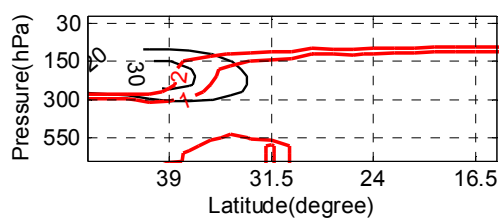

Sep

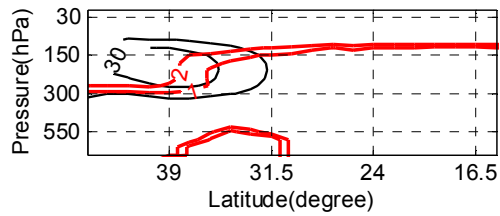

Dec

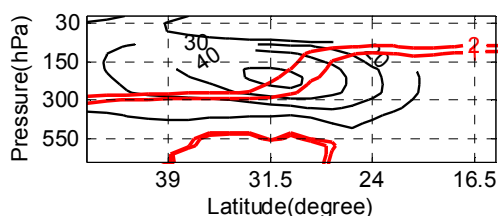

Fig. 7. Pressure-latitude cross-section of monthly average zonal wind (black contours, $\mathrm{m} \mathrm{s}^{-1}$ ) and potential vorticity (PV) (red lines, contours of $1-2$ PVU units) at $90^{\circ} \mathrm{E}$ between $15^{\circ} \mathrm{N}$ and $45^{\circ} \mathrm{N}$ in latitude and between $1000 \mathrm{hPa}$ and $20 \mathrm{hPa}$ in the vertical derived from ERA-40 data of 2008 .

folds rather than zonally aligned folds are observed in the UTLS above the Plateau. The southern downward intrusions of high ozone from the stratosphere to the Plateau troposphere in winter are caused by the meridional folds rather than zonal folds. The intrusions in winter caused by meridional folds are more frequent than in summer. This effect can be one reason for the total column ozone value above the Plateau in winter, higher than that of summer. Recently, a middle tropospheric ozone minimum in June (Liu et al., 2009), and low ozone concentration in the UTLS are observed (Tobo et al., 2008). Liu et al. (2009) explained middle tropospheric ozone minimum with the effect of Asian summer monsoon. Together with the effect of Asian summer monsoon anticyclone, less intrusions of stratospheric air in summer may contribute to the above-mentioned phenomenon of low ozone concentration in the middle and upper troposphere. The high values of tropopause heights above TP in summer contribute also to low total column ozone in summer.

The Dali station $\left(25.71^{\circ} \mathrm{N}, 100.18^{\circ} \mathrm{E}\right)$ has lower frequencies of MT throughout the year (in Table 2), which can be related to the scarce propagation of the westerly jet and folds passing the latitude of the station (Fig. 7). The movement of the jet in a north-south direction is accompanied by the latitudinal movements of tropopause folds, which influence the UTLS structure above the Plateau. The variation of UTLS dynamical structures was reflected by the single or multiple tropopauses observed at the Plateau stations. The observed, two distinctive peak values in LRT1 height distribution in winter could be related to latitudinal movement of folds and jets. Both the heating of the Plateau and poleward extending of tropical tropopause (Pan et al., 2009; Castanheira et al., 2009) can contribute to the observed single high tropopause during IOP2 and IOP3, when the folds retreat northward.

Due to the close relationship between the jets and tropopause folds (Shapiro, 1980), we display the seasonal variations of the jets and tropopause folds (highlighted by 1 and 2 PVU contour lines) to investigate seasonal variation in tropopause structure. Subtropical jet is strengthened by the cooling effect of the Plateau (Ye and Gao, 1979), and is located at the south of the Plateau during winter season. The folds in February and March are the deepest. With the development of the monsoon, subtropical jet weakens and retreats to the north of the plateau, as can be seen by poleward movement of the jet during July. In accordance with the seasonal movement of the jet in a north-south direction, the tropopause folds also move from the south in winter to north in summer. The variation of tropopause folds over the Plateau has also been shown by Sprenger et al. (2003) and the influence of the northward movement of the jet stream by Ding and Wang (2006). Their study attributed summertime maximum of ozone concentration at Waliguan $\left(36.28^{\circ} \mathrm{N}\right.$, 
$100.90^{\circ} \mathrm{E}$, North East of the Plateau) to stratospheric intrusions, which were generally associated with prevailing upper-level jet streams.

\section{Discussion and conclusions}

A set of high resolution radiosonde data above the Tibetan Plateau is used to analyse the thermal tropopause characters. LRT1 (first lapse rate tropopause) over the Plateau has low and high tropopause characters during the winter, and has a consistent high tropopause character in summer. The characteristics of LRT1 observed in our paper was also captured by Tian et al. (2008) using ERA-40 data. Schmidt et al. (2005) also observed the bimodal distribution of LRT1 in the mid-latitudes between 30 and $50^{\circ} \mathrm{N}$ employing GPS radio occultation data. The satellite and reanalysis data have furthered our knowledge about global and climatic characteristics of multiple tropopause (MT). The temporal coverage of our radiosonde dataset is limited and the analysis of Randel et al. (2007) and Añel et al. (2008) represent a climatology on a larger time period including a larger set of data. The vertical and horizontal resolution of our data and dataset used in Randel et al. (2007) and Añel et al. (2008) is different. All make a sound comparison between us and others impossible. The MT statistics over the Tibetan Plateau using ERA40 and GPS data maybe have shortcomings to capture more tropopause. More attention should be paid to the MT events above the Plateau and the influence of the resolution on the statistics of MT. The phenomena of the recent rising trend of MT events (Castanheira et al., 2009) can cause our estimations of MT occurrence in 2008 to be higher than that of the past ten years and this partially explains our results of MT events higher than the climatic value of Randel et al. (2007) and Añel et al. (2008). Whether there are any other significant differences in MT frequencies, this still needs to be testified with higher resolution data of radiosonde.

The dynamical tropopause above the Plateau in pressurelongitude cross-section and pressure-latitude cross-section has been discussed. No folds revealed in pressure-longitude cross-section above the Plateau, which is different from the pressure-latitude cross-section. The dynamical tropopause exhibits a meridional folded structure around the subtropical jet. This folded structure has been demonstrated by radiosonde observations over the Plateau. This paper further shows the close relationship between the folds in pressurelatitude cross-section (meridional folds) and the subtropical jet stream above the Plateau. The meridional folds related with the westerly jet dominate UTLS above the plateau. As Zhang et al. (2010) pointed out, the Plateau terrain has no significant effect on the morphology of folds. The westerly jet maybe the dominative influence on the morphology of the folds above the Plateau.
A persistent maximum of chemical constituents in the UTLS (Park et al., 2009) may also reduce the ozone content in column air above the Plateau. Tian et al. (2008) pointed out that the low column ozone over the TP is rather related to transport than to chemical reactions. We found intrusions of stratospheric air frequently happening in spring time, but it rarely occurs in summer time over the Plateau. Our results support that the reduced southern downward transport of stratospheric air may partially contribute to the phenomena of low ozone content in the middle troposphere and low column ozone in summer time above the Plateau. The height variation of the tropopause, discussed in our paper, can also be used to explain the low value of the total column ozone in summer above the TP.

The lack of high resolution data in the atmosphere has hampered our knowledge about tropopause characteristics so far and limiting our ability to evaluate model performance in UTLS (Hegglin et al., 2010). In addition to our dataset, more radiosonde data with high vertical resolution are indispensable to further quantify tropopause structure and variability above the Tibetan Plateau. Further data are needed for a better understanding of the high MT frequency during winter above the Tibetan Plateau. Discovering that MT frequencies are really high in periods of winter time, this work could further deepen our understanding in UTLS structure over the Plateau. The high-resolution radiosonde data are also an important source of information for studying the thermal structure of UTLS.

\section{Supplementary material related to this article is available online at: http://www.atmos-chem-phys.net/11/5113/2011/ acp-11-5113-2011-supplement.zip.}

Acknowledgements. This research was funded by the National Key Projects for Basic Research of China (2010CB951701), the Chinese National Natural Science Foundation (40825015 and 40810059006), EU-FP7 project "CEOP-AEGIS" (212921), and the Sino-Japan JICA project. Xuelong Chen is supported by the "CAS-KNAW Joint PhD Training Programme". The authors thank all the participants from China and Japan for their very hard field work during the JICA Tibetan Plateau meteorological observations. We thank Laura L. Pan, Cameron Homeyer, J. A., Añel, and William J. Randel for their kind help and discussions during the course of this work. We appreciate both reviewers for their very kind help to improve our manuscript and constructive comments.

Edited by: P. Haynes 


\section{References}

Añel, J. A., Antuña, J. C., de la Torre, L., Nieto, R., and Gimeno, L.: Global statistics of multiple tropopauses from the IGRA database, Geophys. Res. Lett., 34, L06709, doi:10.1029/2006GL029224, 2007.

Añel, J. A., Antuña, J. C., de la Torre, L., Castanheira, J. M., and Gimeno, L.: Climatological features of global multiple tropopause events, J. Geophys. Res., 113, D00B08, doi:10.1029/2007JD009697, 2008.

Beekmann, M., Ancellet, G., Blonsky, S., DeMuer, D., Ebel, A., Elbern, H., Hendricks, J., Kowol, J., Mancier, C., Sladkovic, R., Smit, H. G. J., Speth, P., Trickl, T., and VanHaver, P.: Regional and global tropopause fold occurrence and related ozone flux across the tropopause, J Atmos Chem, 28, 29-44, 1997.

Bian J.: Features of ozone mini-hole events over the Tibetan Plateau, Adv. Atmos. Sci., 26(2), 305-311, 2009.

Castanheira, J. M., Añel, J. A., Marques, C. A. F., Antuña, J. C., Liberato, M. L. R., de la Torre, L., and Gimeno, L.: Increase of upper troposphere/lower stratosphere wave baroclinicity during the second half of the 20th century, Atmos. Chem. Phys., 9, 9143-9153, doi:10.5194/acp-9-9143-2009, 2009.

Cong, C. H., Li, W. L., and Zhou, X. J.: Mass exchange between stratosphere and troposphere over the Tibetan Plateau and its surroundings, Chinese Sci. Bull., 47, 508-512, 2002.

Ding, A. and Wang, T.: Influence of stratosphere-to-troposphere exchange on the seasonal cycle of surface ozone at Mount Waliguan in western China, Geophys. Res. Lett., 33, L03803, doi:10.1029/2005GL024760, 2006.

Duan, A. M. and Wu, G. X.: Role of the Tibetan Plateau thermal forcing in the summer climate patterns over subtropical Asia, Clim. Dynam., 24(7), 793-807, 2005.

Fu, R., Hu, Y., Wright, J. S., Jiang, J. H., Dickinson, R. E., Chen, M., Filipiak, M., Read, W. G., Waters, J. W., and Wu, D. L.: Short circuit of water vapour and polluted air to the global stratosphere by convective transport over the Tibetan Plateau, PNAS, 103(15), 5664-5669, 2006.

Gettelman, A. and de Forster, P. M.: Definition and climatology of the tropical tropopause layer, J. Meteorol. Soc. Jpn, 80:4B, 911924, 2002

Gettelman, A., Hegglin, M. I., Son, S. W., Kim, J., Fujiwara, M., Birner, T., Kremser, S., Rex, M., Añel, J. A., Akiyoshi, H., Austin, J., Bekki, S., Braesike, P., Brühl, C., Butchart, N., Chipperfield, M., Dameris, M., Dhomse, S., Garny, H., Hardiman, S. C., Jöckel, P., Kinnison, D. E., Lamarque, J. F., Mancini, E., Marchand, M., Michou, M., Morgenstern, O., Pawson, S., Pitari, G., Plummer, D., Pyle, J. A., Rozanov, E., Scinocca, J., Shepherd, T. G., Shibata, K., Smale, D., Teyssèdre, H., and Tian, W.: Multimodel assessment of the upper troposphere and lower stratosphere: Tropics and global trends, J. Geophys. Res., 115, D00M08, doi:10.1029/2009JD013638, 2010.

Hegglin, M. I., Gettelman, A., Hoor, P., Krichevsky, R., Manney, G. L., Pan, L. L., Son, S. W., Stiller, G., Tilmes, S., Walker, K. A., Eyring, V., Shepherd, T. G., Waugh, D., Akiyoshi, H., Añel, J. A., Austin, J., Baumgaertner, A., Bekki, S., Braesicke, P., Brühl, C., Butchart, N., Chipperfield, M., Dameris, M., Dhomse, S., Frith, S., Garny, H., Hardiman, S. C., Jöckel, P., Kinnison, D. E., Lamarque, J. F., Mancini, E., Michou, M., Morgenstern, O., Nakamura, T., Olivié, D., Pawson, S., Pitari, G., Plummer, D. A., Pyle, J. A., Rozanov, E., Scinocca, J. F., Shibata, K., Smale, D.,
Teyssèdre, H., Tian, W., and Yamashita, Y.: Multimodel assessment of the upper troposphere and lower stratosphere: Extratropics, J. Geophys. Res., 115, D00M09, doi:10.1029/2010jd013884, 2010.

Holton, J. R.: An Introduction to Dynamic Meteorology, 4 Edn., Elsevier Academic Press, 2004.

Khalili, A.: Some characteristics of the tropopause over Tehran, Pure Appl. Geophys., 113(1), 365-374, 1975.

Liu, Y., Wang, Y., Liu, X., Cai, Z., and Chance, K.: Tibetan middle tropospheric ozone minimum in June discovered from GOME observations, Geophys. Res. Lett., 36, L05814, doi:10.1029/2008GL037056, 2009.

Pan, L. L., Randel, W. J., Gille, J. C., Hall, W. D., Nardi, B., Massie, S., Yudin, V., Khosravi, R., Konopka, P., and Tarasick, D.: Tropospheric intrusions associated with the secondary tropopause, J Geophys. Res., 114, D10302, doi:10.1029/2008JD011374, 2009.

Park, M., Randel, W. J., Emmons, L. K., and Livesey, N. J.: Transport pathways of carbon monoxide in the Asian summer monsoon diagnosed from Model of Ozone and Related Tracers (MOZART), J. Geophys. Res., 114, D08303, doi:10.1029/2008jd010621, 2009.

Randel, W. J., Seidel, D. J., and Pan, L. L.: Observational characteristics of double tropopauses, J. Geophys. Res., 112, D07309, doi:10.1029/2006JD007904, 2007.

Reed, R. J.: A study of a characteristic type of upper-level frontogenesis, J. Atmos. Sci., 12(3), 226-237, 1955.

Schmidt, T., Heise, S., Wickert, J., Beyerle, G., and Reigber, C.: GPS radio occultation with CHAMP and SAC-C: global monitoring of thermal tropopause parameters, Atmos. Chem. Phys., 5, 1473-1488, doi:10.5194/acp-5-1473-2005, 2005.

Shapiro, M. A.: Turbulent Mixing within Tropopause Folds as a Mechanism for the Exchange of Chemical-Constituents between the Stratosphere and Troposphere, J. Atmos. Sci., 37, 994-1004, 1980.

Sprenger, M., Croci Maspoli, M., and Wernli, H.: Tropopause folds and cross-tropopause exchange: A global investigation based upon ECMWF analyses for the time period March 2000 to February 2001, J. Geophys. Res., 108(D12), 8518, doi:10.1029/2002JD002587, 2003.

Steinwagner, J., Milz, M., von Clarmann, T., Glatthor, N., Grabowski, U., Höpfner, M., Stiller, G. P., and Röckmann, T.: HDO measurements with MIPAS, Atmos. Chem. Phys., 7, 26012615, doi:10.5194/acp-7-2601-2007, 2007.

Stohl, A., Bonasoni, P., Cristofanelli, P., Collins, W., Feichter, J., Frank, A., Forster, C., Gerasopoulos, E., Gaggeler, H., and James, P.: Stratosphere-troposphere exchange: a review and what we have learned from STACCATO, J. Geophys. Res., 108(D12), 8516, doi:10.1029/2002JD002490, 2003.

Tian, W., Chipperfield M., and Huang Q.: Effects of the Tibetan Plateau on total column ozone distribution, Tellus B, 60(4), 622635, 2008.

Tobo, Y., Iwasaka, Y., Zhang, D., Shi, G., Kim, Y.-S., Tamura, K., and Ohashi, T.: Summertime "ozone valley" over the Tibetan Plateau derived from ozonesondes and EP/TOMS data, Geophys. Res. Lett., 35, L16801, doi:10.1029/2008GL034341, 2008.

Uppala, S. M., KÅllberg, P. W., Simmons, A. J., Andrae, U., Bechtold, V. D. C., Fiorino, M., Gibson, J. K., Haseler, J., Hernandez, A., Kelly, G. A., Li, X., Onogi, K., Saarinen, S., Sokka, N., Allan, R. P., Andersson, E., Arpe, K., Balmaseda, M. A., Beljaars, 
A. C. M., Berg, L. V. D., Bidlot, J., Bormann, N., Caires, S., Chevallier, F., Dethof, A., Dragosavac, M., Fisher, M., Fuentes, M., Hagemann, S., Hólm, E., Hoskins, B. J., Isaksen, L., Janssen, P. A. E. M., Jenne, R., McNally, A. P., Mahfouf, J. F., Morcrette, J. J., Rayner, N. A., Saunders, R. W., Simon, P., Sterl, A., Trenberth, K. E., Untch, A., Vasiljevic, D., Viterbo, P., and Woollen, J.: The ERA-40 re-analysis, Q. J. Roy. Meteor. Soc., 131, 29613012, doi:10.1256/qj.04.176, 2005.

Xu, X., Zhang, R. H., Koike, T., Lu, C. G., Shi, X. H., Zhang, S. J., Bian, L. G., Cheng, X. H., Li, P. Y., and Ding, G. A.: A new integrated observational system over the Tibetan Plateau, Bull. Am. Meteorol. Soc., 89(10), 1492-1496, 2008.

Yanai, M., Li, C., and Song, Z.: Seasonal heating of the Tibetan Plateau and its effects on the evolution of the Asian summer monsoon, J. Meteor. Soc. Jpn, 70, 319-351, 1992.

Yang, K., Koike, T., Fujii, H., Tamura, T., Xu, X., Bian, L., and Zhou, M.: The daytime evolution of the atmospheric boundary layer and convection over the Tibetan Plateau: observations and simulations, J. Meteor. Soc. Jpn, 82, 1777-1792, 2004.

Ye, D. and Gao, Y.: The meteorology of the Qinghai-Xizang (Tibet) Plateau (in Chinese), Science Press, Beijing, 62-257, 1979.

Zhan, R. F. and Li, J. P.: Influence of atmospheric heat sources over the Tibetan Plateau and the tropical western North Pacific on the inter-decadal variations of the stratosphere-troposphere exchange of water vapour, Sci. China, Ser. D Earth Sci., 51(8), 1179-1193, 2008.
Zhang, M., Tian, W., Chen, L., and Lü, D.: Cross-tropopause mass exchange associated with a tropopause fold event over the northeastern Tibetan Plateau, Adv. Atmos. Sci., 27, 1344-1360, doi:10.1007/s00376-010-9129-9, 2010.

Zhou, S. and Zhang, R.: Decadal variations of temperature and geopotential height over the Tibetan Plateau and their relations with Tibet ozone depletion, Geophys. Res. Lett., 32, L18705, doi:10.1029/2005GL023496, 2005.

Zhou, X., Lou, C., Li, W. L., and Shi, J. E.: Ozone changes over China and low center over Tibetan Plateau, Chin. Sci. Bull. 40, 1396-1398, 1995.

Zou, H.: Seasonal variation and trends of TOMS ozone over Tibet, Geophys. Res. Lett, 23, 1029-1032, 1996.

World Meteorological Organization: Meteorology: A three dimensionalscience, WMO Bull., 6, 134-138, 1957.

SPARC CCMVal: SPARC Report on the Evaluation of ChemistryClimate Models, edited by: Eyring, V., Shepherd, T. G., and Waugh, D. W., SPARC Report No. 5, WCRP-132, WMO/TD-No. 1526, http://www.atmosp.physics.utoronto.ca/ SPARC, 2010. 